\title{
XENOPHOBIA AND NATIONALISM IN THE CONTEXT OF THE INTENSIFICATION OF INTER-ETHNIC CONFLICTS
}

\author{
(C) Olga A. Yanchenkova \\ Platov South-Russian State Polytechnic University (NPI), Novocherkassk, \\ Russian Federation \\ olga-yanchenkova@yandex.ru
}

\begin{abstract}
At present, there is a rather high level of xenophobia in modern Russian society, which is a significant ideological base for ethnic nationalism, increasing intolerance and inter-ethnic tension, which can manifest itself in the form of inter-ethnic conflicts. The shortage of civil confidence in Russian society and the lack of mechanisms for resolving conflicts by civil society forces continue to be a source of xenophobia not only against recent migrants, but also against many representatives of indigenous ethnic groups. This requires a study of xenophobia and nationalism in the context of the intensification of inter-ethnic conflicts. Xenophobia arises and becomes especially noticeable in the case of significant differences of ethnic cultures, and modern nationalism actively resorts to these same differences or even contradictions, trying to form a critical discourse in relation to accepted standards of political correctness, which are really different in Russia from Western ones towards a wider range of what is considered permissible. In addition, nationalism grounded in xenophobia, for example, among the Russian ethnic group, is primarily manifested in the youth environment, which is not least associated with youth maximalism and non-conformism.
\end{abstract}

Key words: nationalism, xenophobia, inter-ethnic conflicts, civil society.

\section{[О.А. Янченкова Ксенофобия и национализм в контексте усиления межэтнических конфликтов]}

В настоящее время можно констатировать довольно высокий уровень ксенофобии в современном российском обществе, который выступает существенной идеологической базой для этнического национализма, усиления нетерпимости и росту межэтнической напряженности, способной проявляться в виде межэтнических конфрликтов. Дефицит в российском обществе гражданского доверия и отсутствие механизмов разрешения конфликтов силами гражданского общества продолжает оставаться источником ксенофобии не только по отношению к недавним мигрантам, но и многим представителям коренных для данной территории этносов. Это требует исследования ксенофобии и национализма в контексте усиления межэтнических конфрликтов. Ксенофобия возникает и становится особенно заметной в случае существенных различий этнических культур и к этим же различиям или даже противоречиям активно прибегает современный национализм, пытающийся сформировать критический дискурс по отношению к принятым стандартам политкорректности, которые правда в России в целом отличаются от западных в сторону более широкого спектра того, что считается дозволенным. Кроме этого, замешанный на ксенофобии национализм, например в среде русского этноса, в первую очередь проявляется в молодёжной среде, что не в последнюю очередь связано с юношеским максимализмом и нонконформизмом.

Ключевые слова: национализм, ксенофобия, межэтнические конфрликты, гражданское общество.

Olga A. Yanchenkova - Lecturer, Platov South-Russian State Polytechnic University (NPI), Novocherkassk, Russian Federation.

Янченкова Ольга Александровна - преподаватель, Южно-Российский государственный политехнический университет (НПИ) имени М.И. Платова, е. Новочеркасск, Российская Федерация.

Nationalism in the system of social interactions can lead to the aggravation of inter-ethnic conflicts and the spread of xenophobia, especially when it comes to ethnocentric nationalism, focused not on the formation of a civil identity, but on the mobilization of representatives of some ethnic community. Historically, during the active phase of the spread of nationalism in the 19th-20th century, which took place against the backdrop of the transition from empires to 
national states, inter-ethnic problems escalated and politicized. Moreover, many ethnic communities that previously existed within large empires (such as Austria-Hungary, Russia, Ottoman Turkey) discovered aspirations to create their own national states or at least national autonomies.

However, the potential of xenophobia was especially evident during the period of mass migration in the late 20th - early 21st centuries, when large masses of immigrants, mainly from African and Asian countries, rushed to the states with a predominant European population [9]. Undoubtedly, the problems related to emigration to one degree or another contributed to the strengthening of defensive trends in the nationalism of the "old" European peoples, partly including the most obvious trends in Russian nationalism, the hallmark of which is the rejection of migrants mainly from the countries of Central Asia and the republics of Transcaucasia.

Interestingly, a significant part of migrants come to the metropolis from former colonies or once dependent territories, or in the case of Russia from the CIS countries. In general, in the modern world there is a "phenomenon of "reverse globalization," in which people move from backward regions of the world (the countries of the Middle East, Africa and South-East Asia) to globalized cities such as London and Paris, Frankfurt and Rome, Madrid and Amsterdam" [1, p. 33]. Moscow and other major Russian cities can be added to this list, the ethnic composition of which, under the influence of internal and external migration, continues to change significantly. Unlike Western countries, xenophobia is observed in Russia not only towards foreigners, but also towards immigrants from certain regions of the own country (for example, especially for the peoples of the North Caucasus who profess Islam), which creates additional difficulties in communication between ethnic communities. Of course, as migrants integrate into Russian society, xenophobia is replaced by a more rational attitude towards each other, but continues to be a breeding ground, a source of motivation for organizing communities of "defensive" nationalism.

At the same time, in modern cultural anthropology, the opinion about the equivalence of a wide variety of cultures (cultural formations), which, however, have different degrees of complementarity towards each other, was established. In this regard, C. Levy-Strauss focused on the fact that "cultures are by nature non-measurable. All the criteria that we can resort to characterize one of them come either from it and, thus, they are devoid of objectivity, or from the other and, therefore, they are untenable" [cit. ex: 3, p. 77]. In most cases, traditions, customs and mentality of newcomers are evaluated from the point of view of their own culture, which to one degree or another bears the features of ethnocentrism.

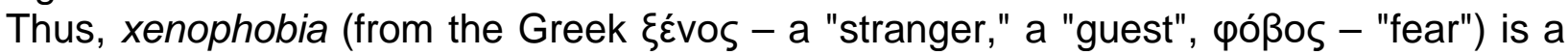
dislike, rejection of representatives of other communities, newcomers (those who have relatively recently appeared in this territory, and seem to be guests). As a specific type of a worldview, xenophobia can become an ideology of racial, ethnic, religious intolerance and hatred. As we have already noticed, increased flows of immigrants and refugees in countries with predominant European populations play a special role in processes of xenophobia spreading and nationalist trends accumulating.

Thus, the migration crisis is becoming a central issue on the political agenda, as well as various discussions and cultural studies. In this regard, I. Wallerstein rightly drew attention to the fact that "the white pan-European world is becoming de facto much less white. Of course, not all migrants are non-white, but they are all defined as such socially" [2, p. 40]. As a result, this leads to a revival of racist ideologies, which largely form the patterns of modern ("white") nationalist resistance, including in Russia. On the other hand, "racism" is an extremely toxic ideology that even modern ethnic nationalists try (at least in words) to reject or ignore. Nevertheless, racism continues to be an important and sort of visible (and accessible) component of xenophobia.

It is obvious that in the conditions of the imperial existence of the state, which is ruled largely by the international aristocracy, the problems associated with ethnic nationalism are 
largely neutralized, although the common people are able to experience xenophobic experiences towards both representatives of the ruling elite and foreigners. The above-described patterns are quite recognizable and distinguishable during the existence of the Russian Empire. However, "deformation of the imperial paradigm (that happened in the wake of the creation of national states) leads to the formation of new identities, intended, it would seem, to preserve, if not strengthen its dominance, but in reality, in the political space of the empire, the "echo" of nationalism of the center is reflected in the "echo" of nationalism of the periphery" [11, p. 99]. Perhaps, in modern Russia, the transition from the empire to the national state, or full-fledged federalism, capable of developing only with the support of a strong civil society, has not actually ended. Moreover, imperial consciousness acts as an important cultural and political pattern of Russian reality, which is also expressed in "phantom" ideas about the lost empire (at the same time, the USSR is also often thought about in imperial discourse).

At the same time, after the collapse of the Soviet Union, Russia turned out to be a relatively ethnically homogeneous state, which is why it was the Soviet heritage (many republics within the country) that "riveted" it to the imperial worldview and the resulting ideology, which is inherently anti-nationalist. Nevertheless, almost all well-known patriarchal empires as they developed, as researchers note, "had to introduce into their lives those elements of modernization in which they were most in need in order to maintain their dominance, but larger reforms gave rise to an increase in nationalism of the periphery, an increase in demands for democratization and liberalization, operating along with a tense confrontation with other empires" [11, p. 100]. Many of the problems associated with peripheral nationalism arose from the requirements of education in the mother tongue, which were also reinforced by historical grievances and economic injustice.

In many cases, state propaganda can institutionalize and even legitimize certain xenophobic patterns regarding an ethnic group, and this process does not always have a conscious character. So, for example, the increased attention of the Russian media to the internal politics of Ukraine and the spread of radical nationalist associations there indirectly forms a negative image of the Ukrainian ethnic group in the minds of the younger generation. Perhaps, in the mass consciousness of the younger generation, instead of the image of a good Ukrainian (a simple-minded "Little Russian" or a cheerful "Uke"), the generalized image of "neo-banderovets" (a cruel pathological Russophobe) has already fully formed.

Therefore, state propaganda is able to dispose of negative emotions of population, directing the latter to an external "alien" enemy. At the same time, xenophobia differs in that its spread significantly reduces the level of rationalization, at the same time, contributes to the mythologization of any people (it is enough to recall the image of Serbs in the Western media in the 90s, or the image of Russians in American cinema or actual media). "External xenophobia," as O.M. Shevchenko notes, "is most often reflected in state ideology, which seeks to assert the status, sovereignty of its state or its people in any way, including violent, for example, by conquering or subjugating someone else's territory. Internal xenophobia is expressed not only in diasporophobia, but also in migrantophobia, which is most often due to socio-economic problems in society. Internal xenophobia can also include the negative attitude of migrants themselves or their descendants towards the indigenous population" [10, p. 60]. Thus, it turns out that xenophobia is a mutual distrust of each other of representatives of different ethnic groups, that is, migrants and representatives of various "national" minorities can also actively demonstrate it.

The integration of new migrants is based on the principle of multiculturalism, based on tolerance and the peaceful existence of different cultures under the auspices of one State, which also involves combating various forms of xenophobia and ethnic nationalism [8].

In practice, however, it turns out that the multiculturalism program fails, as a result of which the problems of inter-ethnic communication grow, while generating forms of reactionary nationalism. At the same time, researchers suggest that "in Russia, multiculturalism is almost 
a natural phenomenon in view of the historical premise of a multicultural situation. The pluralism of peoples, religions, cultures and ethnic groups has always been characteristic for the Russian society. Of course, the Russian authorities often sought national unity through assimilation or "russification" of national minorities" [7, p. 99]. Consequently, Russia has already had its own "homegrown" multiculturalism, which is based on the experience of the long coexistence of various cultures and peoples. So, for example, a significant number of Muslims (by the way, significantly more in percentage terms than in the countries of Western Europe) is not any new or even more "alien" ethnocultural phenomenon for our country.

At the same time, it turns out that manifestations of extremism based on racial, ethnic and confessional hatred (and they often overlap or even coincide) also become the destiny of loneterrorists, largely biased by alarmist sentiments of modern media. Clearly, in today's global world, "multiculturalism has challenged the traditional desire of Europe's nation-states for unity and homogeneity" [12, p. 14]. This led to a significant revision of previous nationalist attitudes and gave rise to nationalism, which is fully oriented towards maintaining ethnic and socio-cultural homogeneity of society. As a part of this format, a discourse of right-wing activists, who deny their own nationalist views, but at the same time, criticize the open-door policy towards migrants, was also formed.

The history of xenophobia in Russia, despite talk of a special Russian path, is indeed similar in many aspects to its Western analogues, at least the main dichotomies: "European/Asian," "white/black," "Russian/Jewish," "Christian/Muslim" are quite clearly traced in it. In this regard, O.M. Shevchenko considers that "in general, an analysis of manifestations of ethno-religious xenophobia in the form of asiatophobia, islamophobia, judephobia, polonophobia, caucasophobia, allows us to conclude that their formation was due to a combination of cultural, historical, socio-political, socio-economic factors in the development of Russian society from the 9th to the beginning of the 20th century:1) the presence of a real or potential external threat from ethnically and religiously "strangers"; 2) the role of Orthodoxy, which formed a complex of ethno-religious exclusivity of the Russian people; 3 ) the intensive process of political and administrative construction of a centralized state, and in the future the empire; 4) the cultural policy of the Russian Empire aimed at the forced cultural unification of the population of territories annexed as a result of wars; 5) the economic modernization processes that contribute to the transformation of large Russian cities into saturated contact ethno-religious zones" [10, p. 326].

At the same time, construction of the Russian statehood unlike countries of Western Europe proceeded in the uniform territory which isn't divided by the seas and oceans that laid the foundation for creation of the uniform communal community capable to create the own and more organic model of integrative multiculturalism. Therefore, the ethnic nationalism feeding on impulses multidirectional (from the majority to the minorities/ from the minority to the majority) xenophobia, can be significantly limited or corrected by the experience of long historical (joint) living in one territory.

The phenomenon of xenophobia itself, which leads to discrimination, is often informal, which makes the possibility of its description and prevention difficult. Moreover, xenophobia itself is quite difficult to identify in sociological surveys, since respondents prefer to deny the presence of this phenomenon in their own minds. It is quite difficult for people to admit to themselves that, in the age of unprecedented in the world history development of science and technology, they experience an almost "mystical" irrational fear in relation to other people. "The attention of human rights organizations is traditionally focused on institutional," as L.M. Drobizheva rightly notes, "that is, in one form or another authorized, discrimination, but its informal (household) analogue is no less scary. For example, it is well known that there is an outflow of Russians in the republics, especially in the North Caucasian republics. This is a real indicator of the state of social well-being of people. The reason is not only in socio-economic conditions (it is easier for Russians to find work in the central regions and be accepted by the 
surrounding population), but also in psychological discomfort, and sometimes discrimination, which is most often associated with appointments to posts" [6, p. 143]. Latent discrimination in many versions is also due to latent xenophobia and nationalist tendencies, which are usually not openly declared.

If we consider the above-mentioned problem from a different perspective, it will turn out that the cultural discomfort experienced by representatives of individual ethnic groups (especially the so-called "ethnophors") in relation to the dominant culture of the region does not indicate, at least, direct (conscious) discrimination. At the same time, the deliberate destruction of identities, more related to frustration and social dissatisfaction, does not always lead to positive results. It often turns out that not all ethnic communities have the same susceptibility to the "lessons" of tolerance.

In fact, we are constantly confronted with the borders of xenophobia, which are not always clearly defined, and most importantly can be interpreted differently by representatives of different ethnic communities living in the region. Sometimes it is found that the practical protection of minorities from discrimination of (ethnic) majority leads to the increase in xenophobia and discrimination against the latter. In this regard, it turns out that minorities are capable of greater ethnic mobilization and solidarity, as well as overcoming class disunity. In addition, the following question arises. Who and in what territory is it necessary to be recognized as minorities by providing them with appropriate state support?

At the same time, Russian cultural policy as a whole is based on the dominants of primordialism (while in Western countries ethnic policy is based on a constructivist approach [5]), at least in relation to "indigenous" ethnic minorities, which are, in most cases, sub-states, that gives the federal structure of the country as a whole asymmetric nature. "In Russian mentality, ethnic values are priority," as researchers emphasize, that is, they are based on the recognition of traditions, the heritage that allows to preserve ethnos. As part of the optimization of interethnic relations at the regional level, the principle of national-cultural community, focused on the preservation of ethnic identity, is a priority" [4, pp. 19-20]. Thus, it turns out that the state is aimed at maintenance of ethnic traditional cultures, languages, crafts connected, as a rule, with the certain politically stratified territory.

\section{Лumepamypa}

1. Бенхабиб С. Притязания культуры. Равенство и разнообразие в глобальную эпоху. М.: Логос, 2005. 3556 с.

2. Валлерстайн И. Утопийское, или исторические возможности XXI века // Прогнозис. Весна, 2006. № 1(5). С. 8-56.

3. Вальденфельс Б. Своя культура и чужая культура. Парадокс науки о «Чужом» // Вальденфрельс Б. Мотив Чужого. Минск: Пропилеи, 1999. 300 с.

4. Волков Ю.Г., Дегтярев А.К., Воденко К.В. Ценностная политика в контексте совершенствования межнациональных отношений на региональном уровне // Гуманитарий Юга России. 2017. № 4. С.14-24.

5. Волков Ю.Г., Денисова Г.С., Лубский А.В. Политика и практика мультикультурализма в западных странах: эксперты о возможности использования его опыта в российских условиях // ПОИСК: Политика. Обществоведение. Искусство. Социология. Культура. 2017. №4 (63). С.72-86.

6. Дробижева Л.М. Этничность в социально-политическом пространстве Российской Федерации. Опыт 20 лет. М.: Новый хронограф, 2013. 336 с.

7. Кузина С.И. Мультикультурализм и этническая идентичность // Философия права. 2012. №5(54). С.98-102.

8. Лапин Д.В. Мультикультурализм: политическая концепция и научный феномен // Идеи и идеалы. 2013. Т.2. №2(16). С.20-26. 
9. Харт М., Негри А. Империя. М.: Праксис, 2004. 244 с.

10. Шевченко О.М. Ксенофробия как фрактор угрозы национальной безопасности государств и политической стабильности в черноморско-каспийском регионе // Россия и мусульманский мир. 2016. № 4 (286). С. 59-68.

11. Шишков В.В. Имперская парадигма: испытание модернизацией и национализмом // Вестник Пермского университета. Серия: Политология. 2013. № 1 (21). С. 92101.

12. Shavit U. Should Muslims Integrate into the West? // Middle East Quarterly. Fall, 2007. C. 13-21.

\section{References}

1. Benkhabib S. Pritiazaniia kultury. Ravenstvo i raznoobrazie v globalnuiu epokhu [Claims of culture. Equality and diversity in the global age]. Moscow: Logos. 2005. 3556 p. (in Russian).

2. Wallerstein I. Utopiiskoe, ili istoricheskie vozmozhnosti $X X I$ veka [Utopian, or historical possibilities of the $21^{\text {st }}$ century]. Prognozis. Vesna 2006. No. 1(5). pp. 8-56 (in Russian).

3. Waldenfels B. Svoia kultura i chuzhaia kultura. Paradoks nauki o "Chuzhom" [Its own culture and foreign culture. The paradox of the science of "Alien"]. Waldenfels B. Motiv Chuzhogo [Alien's motive]. Minsk: Propilei. 1999. 300 p. (in Russian).

4. Volkov Iu.G., Degtiarev A.K., Vodenko K.V. Tsennostnaia politika v kontekste sovershenstvovaniia mezhnatsionalnykh otnoshenii na regionalnom urovne [Value policy in the context of improving interethnic relations at the regional level]. Gumanitarii luga Rossii [Humanist of the South of Russia]. 2017. No. 4. pp.14-24 (in Russian).

5. Volkov Iu.G., Denisova G.S., Lubskii A.V. Politika i praktika multikulturalizma v zapadnykh stranakh: eksperty o vozmozhnosti ispolzovaniia ego opyta v rossiiskikh usloviiakh. [Politics and practice of multiculturalism in Western countries: experts on the possibility of using its experience in Russian conditions]. POISK: Politika. Obshchestvovedenie. Iskusstvo. Sotsiologiia. Kultura [Politics. Social studies. Art. Sociology. Culture]. 2017. No. 4(63). pp. 72-86 (in Russian).

6. Drobizheva L.M. Etnichnost v sotsialno-politicheskom prostranstve Rossiiskoi Federatsii. Opyt 20 let [Ethnicity in the socio-political space of the Russian Federation. Experience 20 years]. Moscow: Novyi khronograf. 2013. 336 p. (in Russian).

7. Kuzina S.I. Multikulturalizm i etnicheskaia identichnost. Filosofiia prava [Multiculturalism and ethnic identity. Philosophy of law]. 2012. No. 5(54). pp. 98-102 (in Russian).

8. Lapin D.V. Multikulturalizm: politicheskaia kontseptsiia i nauchnyi fenomen. Idei i idealy [Multiculturalism: a political concept and a scientific phenomenon. Ideas and ideals]. 2013. V. 2. No. 2(16). pp. 20-26 (in Russian).

9. Khart M., Negri A. Imperiia [Empire]. Moscow: Praksis, 2004. 244 p. (in Russian).

10. Shevchenko O.M. Ksenofobiia kak faktor ugrozy natsionalnoi bezopasnosti gosudarstv i politicheskoi stabilnosti $v$ chernomorsko-kaspiiskom regione. Rossiia i musulmanskii mir [Xenophobia as a factor of threat to the national security of states and political stability in the Black Sea-Caspian region. Russia and the Muslim world]. 2016. No. 4 (286). pp. 59-68 (in Russian).

11. Shishkov V.V. Imperskaia paradigma: ispytanie modernizatsiei i natsionalizmom. Vestnik Permskogo universiteta. Seriia: Politologiia [Imperial paradigm: a test of modernization and nationalism. Bulletin of Perm University. Series: Political Science]. 2013. No. 1 (21). pp. 92-101 (in Russian).

12. Shavit U. Should Muslims Integrate into the West? Middle East Quarterly. Fall, 2007. pp. 13-21.

30 March, 2021 